\title{
PERBEDAAN PENGARUH INFUSA KUNYIT (CURCUMA LONGA) DENGAN INFUSA KELOR (MORINGA OLEIFERA) UNTUK PENCEGAHAN KERUSAKAN PADA ORGAN LAMBUNG, ORGAN HATI, ORGAN GINJAL DAN ORGAN TESTIS TIKUS YANG DIINDUKSI ACETOSAL
}

\author{
Joko Santoso ${ }^{1}$, Dwi Retna Prihati ${ }^{2}$, Syahran Wael ${ }^{3}$ \\ ${ }^{1}$ Poltekkes Permata Indonesia Jogyakarta Indonesia \\ ${ }^{2}$ Poltekkes Kemenkes Surakarta Indonesia \\ ${ }^{3}$ Universitas Pattimura Ambon Indonesia
}

\begin{abstract}
Background: Continuous use of acetosal can result in an increase in the amount of free radicals in the body which can damage cells. Turmeric contains vitamin $C$ which can neutralize superoxide free radicals, hydrogen and hydroxyl peroxides. Moringa contains plavanoids which can capture superoxide, peroxide and hydroxyl free radicals. Objective to see differences in the effect of turmeric and Moringa in preventing cell damage due to acetosal. Method: The research design used was experiment laboratory post test design. A total of 10 rats were divided into 2 groups. Group 1 (given acetosal $(90 \mathrm{mg}) /$ rat and turmeric extract (100 $\mathrm{mg} / 200 \mathrm{mg} \mathrm{BB}$ ), group 2 (given acetosal (90 $\mathrm{mg}$ ) / rat and Moringa extract (200 mg / $200 \mathrm{mg} \mathrm{BB}$ ). Results: Oral treatment for seven days The results showed turmeric and moringa had the same effect on the prevention of gastric organ damage $(p=1.0)$, liver $(p=0.4)$, kidney $(p=0.65)$ and testicles $(p=>$ 5). Conclusion: Turmeric infusion and Moringa infusion are equally good for preventing cell damage.
\end{abstract}

Keywords: Acetosal, Damage To The Stomach, Liver, Kidneys, Testicles

\section{PENDAHULUAN}

Obat anti inflamasi non steroid (NSAID) merupakan kelompok obat yang paling banyak dikonsumsi diseluruh dunia untuk mendapatkan efek analgetik, antipiretik dan anti inflamasi. Obat ini merupakan salah satu kelompok obat yang paling banyak diresepkan dan digunakan tanpa resep dokter. Salah satu obat yang sering digunakan dan merupakan prototipe awal adalah asetosal (Wilmana dan Gan, 2007). Acetosal merupakan salah satu turunan asam salisilat yang berfungsi sebagai analgesik. mekanisme kerja menghambat biosintesis prostaglandin. Prostaglandin (mediator nyeri) adalah hormon yang dihasilkan di dalam tubuh dan mempunyai efek menghambat proses penghantaran rangsangan sakit ke otak. Proses perjalanan obat (asetosal) dari diminum sampai menimbulkan efek di organ target bukannya tanpa risiko. Setiap sel pada organ termasuk lambung, hati, ginjal, dan testis yang dilalui akan memberikan respon dan tetap saja asetosal adalah zat asing yang dapat menimbulkan risiko negatif. Karena alasan inilah perlu alternatif adanya pencegahan kerusakan lebih lanjut dari efek obat (asetosal) yaitu salah satunya berasal dari herbal (BPOM, 2008).

Keputusan Menteri Kesehatan RI Nomor 121/MEI/KES/SK/III/2008 bahwa dalam rangka meningkatkan pelayanan kesehatan yang aman, dan dapat dipertanggung jawabkan, perlu 
dimanfaatkan berbagai upaya kesehatan termasuk pelayanan medik herbal sebagai bagian dari pengobatan komplementer alternatif (DepKes, 2008). Tanaman herbal bisa berupa daun-daunan, kulit batang, buah, serta rimpang (akar-akaran). Di Indonesia sendiri memiliki kekayaan dengan aneka ragam tumbuhan, setidaknya terdapat sekitar 940 jenis diantara puluhan ribu jenis tanaman yang telah diketahui mempunyai khasiat obat. Dari semua jumlah tersebut baru 250 jenis yang sudah dimanfaatkan dalam industri jamu dan dijadikan alternatif obat tradisional termasuk kunyit dan kelor.

Kunyit (Curcuma Longa) mempunyai kandungan vitamin $\mathrm{C}$ yang berperan sebagai antioksidan (kemenkes, 2010). Vitamin $C$ ini menetralkan radikal anion superoksida, radikal peroksida hidrogen, dan radikal hidroksil (Percival, 1998). Kelor (Moringa Oleifera) mengandung derivat flavonoid menunjukkan beberapa aktivitas biologi dikaitkan dengan sifat antioksidan antara lain kemampuan menangkap radikal bebas dan spesi oksigen reaktif seperti anion superoksida dan radikal hidroksil (Morikawa et al., 2003; Schmalhausen et al., 2007). Dari uraian diatas peneliti tertarik untuk untuk meneliti lebih lanjut tentang pengaruh infusa kunyit dan infusa kelor terhadap lambung, hati, ginjal, dan testis yang diinduksi asetosal.

\section{METODE PENELITIAN}

Jenis penelitian ini adalah exsperimental laboratory. Rancangan penelitian yang digunakan adalah Randomized post test group. Uji beda yang digunakan adalaah Chi square .

Hewan uji yang digunakan dalam penelitian ini adalah tikus putih (Rattus norwegia) jantan, galur Wistar. Kriteria hewan uji dalam penelitian ini adalah jenis kelamin jantan, umur 2-3 bulan, berat badan 200 gram, sehat yang memiliki ciri yaitu gerak aktif dan nafsu makan baik, tidak ada kelainan anatomi maupun fisik. 5 ekor tikus diberikan acetosal $(90 \mathrm{mg}) /$ tikus dan ekstrak kunyit $(100 \mathrm{mg} / 200 \mathrm{mg}$ BB dan 5 ekor tikus diberikan 5 ekor acetosal $(90 \mathrm{mg}) /$ tikus dan ekstrak kelor (200 mg/200mg BB.

Perlakuan secara oral selama tujuh hari. Infusa ramuan diberikan setiap hari pada jam 09.00 WIB selama 7 hari berturut-turut kemudian setelah 10 menit perlakuan tersebut maka masing-masing diinduksi dengan asetosal. Pada hari ke-8 hewan uji dipuasakan selama 24 jam dengan pemberian minum ad libitum. Setelah 24 jam hewan dianestesi dan dibedah untuk diambil organnya. Pemeliharaan hewan uji di LPPT 4 Universitas Gadjah Mada Yogyakarta dan Pengamatan organ dilakukan secara mikroskopik Laboratorium Histologi Fakultas Kedokteran hewan Universitas Gadjah Mada Yogyakarta.

\section{HASIL PENELITIAN}

A. Pengaruh Infusa Kunyit terhadap pencegahan kerusakan sel pada organ Lambung, Hati, Ginjal, Testis Tikus yang diinduksi Asetosal

Tabel 1. Pengaruh Pengaruh Infusa Kunyit terhadap pencegahan kerusakan sel pada organ Lambung, Hati, Ginjal, Testis Tikus yang diinduksi Asetosal

\begin{tabular}{cllll}
\hline Sampel & Lambung & Hati & Ginjal & Testis \\
\hline 1 & TAP & TAP & NET & TAP \\
2 & IL TM & DM & TAP & TAP \\
3 & IL TM & TAP & DHET & TAP \\
4 & IL TM & DM & TAP & TAP \\
5 & IL TM & TAP & TAP & TAP \\
\hline
\end{tabular}


TAP (Tidak ada perubahan Patologi)

IL TM (Infiltrasi Limfosit di Tunika Mukosa)

DM (Degenerasi Melemak ,ditandai adanya vakuola-vakuola berbagai ukuran dengan batas jelas didalam sitoplasma)

NET (Nekrosis Epithel Tubulus, ditandai inti sel tampak pinotik)

DHET (Degenerasi Hidropik Epithel Tubulus, ditandai sel bengkak dengan sitoplasma bundar)

Dari tabel 1 diatas memperlihatkan bahwa sel yang menunjukkan tidak ada perubahan patologi pada organ lambung (20\%), Hati (60\%), Ginjal (60\%), dan Testis $(100 \%)$

\section{B. Pengaruh Infusa Kelor terhadap pencegahan kerusakan sel organ Lambung, Hati, Ginjal dan Testis Tikus yang diinduksi Asetosal}

Tabel 2. Pengaruh Infusa Kelor terhadap pencegahan kerusakan sel organ Lambung, Hati, Ginjal dan Testis Tikus yang diinduksi Asetosal.

\begin{tabular}{cllll}
\hline Sampel & Lambung & Hati & Ginjal & Testis \\
\hline 1 & IL TM- & DM & TAP & TAP \\
& TSM & & & \\
2 & EE TM & TAP & TAP & TAP \\
3 & TAP & TAP & TAP & TAP \\
4 & IL TM & TAP & TAP & TAP \\
5 & TAP & TAP & TAP & TAP
\end{tabular}

TAP ( Tidak ada perubahan Patologi)

IL TM (Infiltrasi Limfosit di Tunika Mukosa)

IL TSM (Infiltrasi Limfosit di Tunika SubMukosa)

EE TM (Erosi Epitel Tunika Mukosa)

DM (Degenerasi Melemak, ditandai adanya vakuola-vakuola berbagai ukuran dengan batas jelas didalam sitoplasma)
Dari tabel 2 diatas memperlihatkan bahwa sel yang menunjukkan tidak ada perubahan patologi pada organ lambung (40\%), Hati (80\%), Ginjal (100\%), dan Testis $(100 \%)$

C. Perbedaan Pengaruh Infusa Kunyit dengan Kelor terhadap pencegahan kerusakan sel pada organ Lambung, Hati, Ginjal dan Testis Tikus yang diinduksi Asetosal

Tabel 3. Perbedaan Pengaruh Infusa Kunyit dengan Kelor terhadap pencegahan kerusakan sel pada organ Lambung , Hati, Ginjal dan Testis Tikus yang diinduksi Asetosal

\begin{tabular}{ll}
\hline \multicolumn{1}{c}{ Organ } & $\mathrm{P}$ \\
\hline Lambung & 1,00 \\
Hati & 0,4 \\
Ginjal & 0,655 \\
Testis & $>0,05$ \\
\hline
\end{tabular}

Dari tabel 3 diatas terlihat bahwa tidak ada beda pengaruh antara Infusa Kunyit dan Infusa Kelor terhadap kerusakan lambung, hati, ginjal, testis tikus yang diinduksi Asetosal. Ini artinya infusa kunyit dan infusa kelor sama sama mempunyai efek yang baik untuk memproteksi kerusakan organ akibat asetosal.

\section{PEMBAHASAN}

Acetosal yang masuk kedalam tubuh dideteksi sebagai sebagai zat asing (Xenobiotik). Semakin banyak acetosal yang masuk maka semakin tinggi pula konsumsi oksigen untuk menghasilkan ATP (Bharatawijaya, 2004). Fenomena ini mencerminkan pemakaian cepat oksigen (respiratory burst) dan pembentukan sejumlah besar reactive oxygen species (ROS). Apabila ROS lebih banyak daripada yang dapat dibuang oleh mekanisme tubuh, maka berpotensi 
menyebabkan oxydative stress. Apabila stress oksidatif ini berlangsung lama maka dapat mengakibatkan cidera bahkan kematian sel. Sistem respiratory burst menyebabkan terjadinya peroksida lemak. Peroksida lemak selalu mengubah/ merusak struktur molekul lemak dan menyebabkan penurunan persentase lemak seperti kolesterol dan phospolipid. Apabila lemak yang dirusak adalah suatu membran biologis sel maka susunan lapisan ganda lemak dan strukural organisasi yang ada didalam sel menjadi terganggu. Peroksida lemak dimembran sel akan mengakibatkan peningkatan permeabilitas sel sehingga molekul seperti, $\mathrm{Na}^{+}, \mathrm{Ca}^{2+}, \mathrm{H}_{2} \mathrm{O}$, dll yang berada diluar sel dapat masuk secara besarbesaran dan menyebabkan pembengkakan sel, menurunnya integritas membran sel bahkan sampai lisis, kerusakan mitokondria, kerusakan DNA inti (terjadi pemutusan rantai), dan jenis kerusakan lain yang mengganggu fungsi sel, termasuk sel-sel organ lambung, hati, ginjal, dan testis (Dawn B,2000; Wiknjosastro G,2008; Narendra M, 2008)

Hasil penelitian Joko Santoso (2015) menyebutkan bahwa infusa Kunyit dapat mengurangi kerusakan jumlah lesi pada mukosa lambung $(\mathrm{p}=0,03)$ dan protektor pada infusa kelor $(\mathrm{p}=0,005)$. Kunyit (Curcuma Longa) mempunyai kandungan vitamin $\mathrm{C}$ yang berperan sebagai antioksidan (kemenkes, 2010). Vitamin $\mathrm{C}$ ini menetralkan radikal anion superoksida, radikal peroksida hidrogen, dan radikal hidroksil (Percival, 1998). Kelor (Moringa Oleifera) mengandung derivat flavonoid menunjukkan beberapa aktivitas biologi dikaitkan dengan sifat antioksidan antara lain kemampuan menangkap radikal bebas dan spesi oksigen reaktif seperti anion superoksida dan radikal hidroksil (Morikawa et al., 2003; Schmalhausen et al., 2007). Plavanoid berfungsi sebagai antioksidan yang mampu menstabilkan radikal bebas karena adanya gugus hidroksi fenolik. Asam siringat juga mempunyai gugus hidroksi fenolik yang mampu mendonorkan hidrogen pada senyawa radikal (Daniel, 2006; Pokorny dkk, 2001).Dari uraian diatas peneliti tertarik untuk untuk meneliti lebih lanjut tentang pengaruh infusa kunyit dan infusa kelor terhadap lambung, hati, ginjal, dan testis yang diinduksi asetosal. Dengan ditangkap dan dinetralisirnya radikal bebas maka proses peroksida lipid dapat dihambat sehingga mencegah kerusakan sel.

\section{KESIMPULAN DAN SARAN}

Hasil uji satatistik menunjukkan bahwa tidak ada perbedaan yang bermakna antara infusa kunyit dan infusa kelor dalam pencegahan kerusakan organ lambung, hati, ginjal, testis tikus yang diinduksi Asetosal.

Disarankan bagi orang yang mengkonsumsi asetosal bisa mencegah kerusakan sel dengan mengkonsumsi kunyit atau kelor.

\section{DAFTAR RUJUKAN}

BPOM, 2008. Informatorium Obat Nasional Indonesia, 690-692.

Daniel M, 2006. Medical plants chemistry and properties, science publishers, enfield, NH, USA

Dawn B. Marks, Allan D. Marks, Collen Smit M.. Biokimia Kedokteran Dasar. EGC: Jakarta; 2000. hal 321-358

Depkes RI, 2008. Farmakope herbal indonesia, Edisi I, Jakarta. 
Kemenkes RI, 2010. Vademekum tanaman obat untuk saintifikasi jamu. Jakarta: Kemenkes RI.

Narendra M., Kavitha G., Padmavathi P. Alletrin Induced Biochemical Changes And Properties Of Human Erythrocyte. African Journal Of Biochemistry Research. 2008 vol 2 no1 hal 24-29

Percival, M.1998. Antioxidants advanced Nutrition Publication. Inc

Pokorny J., Yanishlieva N.,and Bordon M., 2001. Antioksidant in food, Practical Aplication, C\&C Press, New York.

Schmalhausen, E. V., Zhlobek, E. B., Shalova, I. N., Firuzi, O., Saso, L., and Muronetz, V. I., 2007, Antioxidant and prooxidant effects of quercetin on glyceraldehyde-3phosphate dehydrogenase. Food and Chemical Toxicology, 45, 1988-93

Wilmana P. F., dan Gan S., 2007. Farmakologi dan terapi. Edisi VI. Jakarta : Gaya Baru, pp : 230-46, 273-87, 817. 